\title{
Sleep Disturbances and Association of Polymorphism rs2278749 Gene ARNTL in Male Population 25 - 44 Years in Russia/Siberia
}

\section{Valery Gafarov ${ }^{1,2 *}$, Elena Gromova ${ }^{1,2}$, Dmitriy Panov ${ }^{1,2}$, Igor Gagulin $^{1,2}$, Almira Gafarova ${ }^{1,2}$ and Eldar Krymov ${ }^{1,2}$}

${ }^{1}$ Collaborative Laboratory of Cardiovascular Diseases Epidemiology, Novosibirsk, Russia

${ }^{2}$ Institute of Internal and Preventive Medicine - Branch of Institute of Cytology and Genetics SB RAS, Novosibirsk, Russia

*Corresponding Author: Valery Gafarov, Doctor of Sciences (Medicine), Professor, Head of Laboratory of Psychological and Sociological Issues of Internal Diseases, Institute of Internal and Preventive Medicine - Branch of Institute of Cytology and Genetics SB RAS, Head Collaborative laboratory of Cardiovascular Diseases Epidemiology, Novosibirsk, Russia.
Received: October 23, 2020

Published: November 18, 2020

(C) All rights are reserved by Valery Gafarov., et al.

\section{Abstract}

It was found that the most common genotype rs2278749 ARNTL gene was homozygous C/C genotype - 74,9\%. Prevalence of C/T and $\mathrm{T} / \mathrm{T}$ genotype was $22.3 \%$ and $2.8 \%$, respectively. It was revealed that persons with the genotype $\mathrm{C} / \mathrm{T}$ more likely to experience serious conflicts in the family, more experienced their frustration, they often have disturbing dreams, and they wake up tired and exhausted, in addition, they often met the high level of the life of exhaustion, and they soon became frustrated. Persons with genotype $\mathrm{T} / \mathrm{T}$ often took the trouble "to heart" and were more punctual. On the other hand, persons with C/C genotype were more hostile, were inclined not to trust anyone, almost "never" accept negative situations "close to the heart" and much less experienced disturbing dreams.

Keywords: The ARNTL Gene; Genetic Polymorphism; rs2278749; Sleep Disorders; Psychosocial Factors

\section{Introduction}

Affective disorders are currently thought to be responsible for approximately $1 \%$ of all deaths and can also lead to disability [1]. Emotional disturbances, such as anxiety, vital exhaustion, hostility, have a number of features that are directly related to a person's biological clock. For example, disturbance of circadian rhythms is one of the symptoms of major depressive disorder, or clinical depression - a condition characterized by a whole set of symptoms, including impaired sleep and appetite, decreased mood, loss of energy and suicidal ideation [2,3]. Some authors attribute the exacerbation and remission of affective disorders to the violation of the sleep-wake cycle $[3,4]$. Other authors have noted some clinical signs indicating circadian disorders, such as early awakening, shortening of the REM sleep phase, and other factors leading to sleep disturbance [5].

Over the past few years the molecular genetic causes of changes in circadian rhythms discovered in various organisms, including mammals [6]. Affective disorders can occur due to dysfunctions of the circadian oscillator, i.e. violations of cyclic fluctuations in the intensity of various biological processes associated with the change of day and night. The primary circadian oscillator in mammals is located in the suprachiasmatic nucleus and produces an almost 24-hour cycle through the interaction of positive/negative feedback loops. 
It consists of the main helix-loop-helix-DNA transcription factors CLOCK and ARNTL (BMAL1), which act as positive regulators, as well as negative regulators PER1, Per2, PER3, CRY1 and CRY2 [7]. The ARNTL gene is a key element of the positive feedback of the molecular circadian oscillator [8]. According to the activity of a number of genes, Jun Z Li., et al. 2013 [9] were able to determine that in people suffering from depression: circadian rhythms are altered, and "nocturnal" genes were expressed during the day. It has been suggested that desynchronization may occur due to a disruption of link between individual circadian genes.

Thus, taking into account the influence of gene mechanisms at the molecular and genetic level on circadian rhythms we set out to explore the association of rs2278749 polymorphism of the ARNTL gene with some components of affective disorders and sleep disturbances in the male population of 25 - 44 years in Novosibirsk.

\section{Materials and Methods}

In frame of an epidemiological study A random representative sample of the male population aged 25 - 44 years in one of Novosibirsk city district was examined in 2014 - 2016. By random method 179 men were selected (mean age was 35.5 years) who underwent psychosocial testing. Testing conducted with using of "4-item Jenkins Sleep Questionnaire" (JSQ) - violation of the quality and duration of sleep (CD Jenkins., et al.) [10]. Depression and anxiety testing was conducted with a modified questionnaire (25 item) of the Welsh Depression subscale of the MMPI (15 item) and Bendig Anxiety subscale of the MMPI (10 item). Vital Exhaustion was assessed with The Maastricht Questionnaire (MQ) (short version, 14 - item). A questionnaire "Knowledge and attitude to one's health" was also proposed. Respondents independently answered the test questions. Respondents answered the test questions in the way they currently feel. The questionnaires were validated for the Russian population during a large-scale epidemiological study carried out as part of the WHO MONICA program (Multinational Monitoring of Trends and Determinants of Cardiovascular Disease) and subroutines MONICA-Psychosocial Optional Study (MOPSY) $[11,12]$.

In addition, in the men included in the study, the frequency distribution of the rs2278749 genotypes of the ARNTL gene was studied. Using molecular genetic methods, the polymorphic variants rs2278749 of the ARNTL gene were studied. Genomic DNA was isolated from venous blood by phenol - chloroform extraction. Gene polymorphism was tested by real-time PCR in accordance with the manufacturer's protocol (TaqMan probes, Applied Biosystems, USA) using an ABI 7900HT instrument.

Statistical analysis was performed using the software package SPSS 11.5 [13] and Epi Info 7 [14]. Differences in the frequency distribution rs2278749 of the ARNTL gene between groups were evaluated using the Chi square $(\chi 2)$ criterion. P values $<0.05$ were considered statistically significant.

The study was examined by the local committee on biomedical ethics (protocol No. 4 of 10/15/2009).

\section{Results}

Table 1 presents the frequency distribution of the rs2278749 genotypes of the ARNTL gene among men 25 - 44 years old in Novosibirsk.

The most common genotype rs 2278749 of the ARNTL gene was the $\mathrm{C} / \mathrm{C}$ homozygous genotype - 74.9\%. The second most prevalent heterozygous C/T genotype was in $22.3 \%$ and only $2.8 \%$ of the population had the $\mathrm{T} / \mathrm{T}$ homozygous genotype.

Table 2 presents the frequency distribution of the rs2278749 genotypes of the ARNTL gene depending on psychological characteristics.

To the question: "Have you had any serious conflicts in your family over the past 12 months? the persons with $\mathrm{C} / \mathrm{T}$ genotype responded "frequently" (10\%). The answer 'several occasions" noted in persons with $\mathrm{C} / \mathrm{T}(15 \%)$ and $\mathrm{C} / \mathrm{C}$ genotype $(11.2 \%)\left(\chi^{2}=16.81\right.$ $\mathrm{df}=6 \mathrm{p}=0.01$ ). In contrast, persons with the T/T genotype "often" (40\%) and "almost always" (20\%) took everything "too close to the heart". While persons with C/T (40\%) and C/C genotype (47.4\%) more often answered - "never". Persons with the $\mathrm{C} / \mathrm{T}$ genotype more often than others (25\%) confirmed that they are so worried about their disappointments that they cannot forget about them for a long time compared with persons with the $\mathrm{C} / \mathrm{T}$ genotype $(14.2 \%)\left(\chi^{2}=12.3 \mathrm{df}=6 \mathrm{p}<0.05\right)$.

\begin{tabular}{|l|c|c|}
\hline Genotypes & N & \% \\
\hline T/T & 5 & 2,8 \\
\hline C/T & 40 & 22,3 \\
\hline C/C & 134 & 74,9 \\
\hline Total & 179 & 100 \\
\hline
\end{tabular}

Table 1: Frequency distribution of genotypes rs2278749 of the ARNTL gene among men 25-44 years old in Novosibirsk. 


\begin{tabular}{|c|c|c|c|c|c|c|c|c|c|}
\hline \multirow{3}{*}{$\begin{array}{l}\text { a } \\
\text { Test "Knowledge and attitude to your health" } \\
\text { Question: "Have you had any serious conflicts } \\
\text { in your family } \\
\text { in the last } 12 \text { months?" }\end{array}$} & \multicolumn{9}{|c|}{ Type of $A R N T L$ gene, rs2278749 } \\
\hline & \multicolumn{2}{|c|}{$\mathrm{T} / \mathrm{T}$} & \multicolumn{2}{|c|}{$\mathrm{C} / \mathrm{T}$} & \multicolumn{3}{|c|}{\begin{tabular}{c|c}
$\mathrm{C} / \mathrm{C}$ \\
\end{tabular}} & \multicolumn{2}{|c|}{ Total } \\
\hline & $\mathbf{N}$ & $\%$ & $\mathbf{N}$ & $\%$ & $\mathbf{N}$ & \multicolumn{2}{|c|}{$\%$} & $\mathbf{N}$ & $\%$ \\
\hline Did not have & 5 & 100 & 25 & 62.5 & 103 & \multicolumn{2}{|c|}{76.9} & 133 & 74.3 \\
\hline Once & 0 & 0 & 5 & 12.5 & 16 & \multicolumn{2}{|c|}{11.9} & 21 & 11.7 \\
\hline Several & 0 & 0 & 6 & 15 & 15 & \multicolumn{2}{|c|}{11.2} & 21 & 11.7 \\
\hline It is often & 0 & 0 & 4 & 10 & 0 & \multicolumn{2}{|c|}{0} & 4 & 2.2 \\
\hline Total & 5 & 100 & 40 & 100 & 134 & \multicolumn{2}{|c|}{100} & 179 & 100 \\
\hline \multicolumn{10}{|l|}{$\chi^{2}=16.81 \mathrm{df}=6 \mathrm{p}=0.01$} \\
\hline & \multicolumn{9}{|c|}{ Type of $A R N T L$ gene, rs2278749 } \\
\hline Spielberger test & \multicolumn{2}{|c|}{$T / T$} & \multicolumn{2}{|c|}{$\mathrm{C} / \mathrm{T}$} & \multicolumn{3}{|c|}{$\mathrm{C} / \mathrm{C}$} & \multicolumn{2}{|c|}{ Total } \\
\hline Answer: "I am calm, cool and reassembled." & $\mathrm{N}$ & $\%$ & $\mathrm{~N}$ & $\%$ & $\mathrm{~N}$ & \multicolumn{2}{|c|}{$\%$} & $\mathrm{~N}$ & $\%$ \\
\hline 1. Almost never & 1 & 20 & 0 & 0 & 1 & \multicolumn{2}{|c|}{0.7} & 2 & 1.1 \\
\hline 2.Never & 1 & 20 & 18 & 45 & 32 & \multicolumn{2}{|c|}{23.9} & 51 & 28.5 \\
\hline 3.0ften & 2 & 40 & 15 & 37.5 & 70 & \multicolumn{2}{|c|}{52.2} & 87 & 48.6 \\
\hline 4. Almost always & 1 & 20 & 7 & 17.5 & 31 & \multicolumn{2}{|c|}{23.1} & 39 & 21.8 \\
\hline Total & 5 & 100 & 40 & 100 & 134 & \multicolumn{2}{|c|}{100} & 179 & 100 \\
\hline \multicolumn{10}{|l|}{$\chi^{2}=4.44 \mathrm{df}=2 \mathrm{p}=0.108$} \\
\hline & \multicolumn{9}{|c|}{ Type of $A R N T L$ gene, rs2278749 } \\
\hline Spielberger test & \multicolumn{2}{|c|}{$\mathbf{T} / \mathbf{T}$} & & & & $\mathrm{C} / \mathrm{C}$ & & & tal \\
\hline Answer: "I take everything too close to my heart" & $\mathrm{N}$ & $\%$ & $\mathrm{~N}$ & $\%$ & 1 & & $\%$ & $\mathrm{~N}$ & $\%$ \\
\hline 1. Almost never & 1 & 20 & 6 & 15 & 3 & & 28.6 & 45 & 25.3 \\
\hline 2.Never & 1 & 20 & 16 & 40 & 6 & & 47.4 & 80 & 44.9 \\
\hline 3.0ften & 2 & 40 & 10 & 25 & 2 & & 20.3 & 39 & 21.9 \\
\hline 4. Almost always & 1 & 20 & 8 & 20 & 5 & & 3.8 & 14 & 7.9 \\
\hline Total & 5 & 100 & 40 & 100 & 13 & & 100 & 178 & 100 \\
\hline$\chi^{2}=16.05 \mathrm{df}=6 \mathrm{p}=0.01$ & & & & & & & & & \\
\hline & & & & e of $A$ & RNTL ge & ne, rs2 & 278749 & & \\
\hline Spielberger test & & / $\mathbf{T}$ & & & & /C & & Tota & \\
\hline $\begin{array}{l}\text { Answer: "I am so worried about my frustrations, } \\
\text { then I can't forget about them for a long time". }\end{array}$ & $\mathrm{N}$ & $\%$ & $\mathrm{~N}$ & $\%$ & $\mathrm{~N}$ & $\%$ & $\mathrm{~N}$ & & $\%$ \\
\hline Almost never & 3 & 60 & 9 & 22.5 & 46 & 34.3 & 58 & & 32.4 \\
\hline Never & 2 & 40 & 18 & 45 & 68 & 50.7 & 88 & & 49.2 \\
\hline Often & 0 & 0 & 10 & 25 & 19 & 14.2 & 29 & & 16.2 \\
\hline Almost always & 0 & 0 & 3 & 7.5 & 1 & 0.7 & 4 & & 2.2 \\
\hline Total & 5 & 100 & 40 & 100 & 134 & 100 & 179 & & 100 \\
\hline
\end{tabular}

Table 2a

Citation: Valery Gafarov., et al. "Sleep Disturbances and Association of Polymorphism rs2278749 Gene ARNTL in Male Population 25 - 44 Years in Russia/Siberia". Acta Scientific Neurology 4.2 (2021): 02-08. 


\begin{tabular}{|c|c|c|c|c|c|c|c|c|}
\hline \multirow{3}{*}{$\begin{array}{l}\text { Sleep Disorders Test } \\
\text { How often do you have disturbing visions } \\
\text { during sleep during the last month? }\end{array}$} & \multicolumn{8}{|c|}{ Type of $A R N T L$ gene, rs2278749 } \\
\hline & \multicolumn{2}{|c|}{$\mathrm{T} / \mathrm{T}$} & \multicolumn{2}{|c|}{$\mathrm{C} / \mathrm{T}$} & \multicolumn{2}{|c|}{$\mathrm{C} / \mathrm{C}$} & \multicolumn{2}{|c|}{ Total } \\
\hline & $\mathbf{N}$ & $\%$ & $\mathbf{N}$ & $\%$ & $\mathbf{N}$ & $\%$ & $\mathbf{N}$ & $\%$ \\
\hline Never & 2 & 40 & 10 & 25 & 57 & 42.5 & 69 & 38.5 \\
\hline $1-3$ & 2 & 40 & 12 & 30 & 46 & 34.3 & 60 & 33.5 \\
\hline $4-7$ & 1 & 20 & 11 & 27.5 & 22 & 16.4 & 34 & 19 \\
\hline $8-14$ & 0 & 0 & 2 & 5 & 6 & 4.5 & 8 & 4.5 \\
\hline $15-21$ & 0 & 0 & 2 & 5 & 3 & 2.2 & 5 & 2.8 \\
\hline 22 and more days & 0 & 0 & 3 & 7.5 & 0 & 0 & 3 & 1.7 \\
\hline Total & 5 & 100 & 40 & 100 & 134 & 100 & 179 & 100 \\
\hline \multicolumn{9}{|l|}{$\chi^{2}=16.35 \mathrm{df}=8 \mathrm{p}<0.05$} \\
\hline \multirow{3}{*}{$\begin{array}{l}\text { How often during the last month did you } \\
\text { wake up after a normal sleep tired and } \\
\text { exhausted? }\end{array}$} & \multicolumn{8}{|c|}{ Type of $A R N T L$ gene, rs2278749 } \\
\hline & \multicolumn{2}{|c|}{$\mathrm{T} / \mathrm{T}$} & \multicolumn{2}{|c|}{$\mathrm{C} / \mathrm{T}$} & \multicolumn{2}{|c|}{$\mathrm{C} / \mathrm{C}$} & \multicolumn{2}{|c|}{ Total } \\
\hline & $\mathbf{N}$ & $\%$ & $\mathbf{N}$ & $\%$ & $\mathbf{N}$ & $\%$ & $\mathbf{N}$ & $\%$ \\
\hline Never & 3 & 60 & 14 & 35 & 68 & 50.7 & 85 & 47.5 \\
\hline $1-3$ & 2 & 40 & 8 & 20 & 46 & 34.3 & 56 & 31.3 \\
\hline $4-7$ & 0 & 0 & 12 & 30 & 12 & 9 & 24 & 13.4 \\
\hline $8-14$ & 0 & 0 & 3 & 7.5 & 5 & 3.7 & 8 & 4.5 \\
\hline $15-21$ & 0 & 0 & 3 & 7.5 & 3 & 2.2 & 6 & 3.4 \\
\hline 22 and more days & 0 & 0 & 0 & 0 & 0 & 0 & 0 & 0 \\
\hline Total & 5 & 100 & 40 & 100 & 134 & 100 & 179 & 100 \\
\hline
\end{tabular}

Table $2 \mathbf{b}$

\begin{tabular}{|c|c|c|c|c|c|c|c|c|}
\hline \multirow{3}{*}{$\begin{array}{l}\text { Test "Vital Exhaustion" } \\
\text { Have you ever woken up with a feeling of } \\
\text { exhaustion and fatigue? }\end{array}$} & \multicolumn{8}{|c|}{ Type of $A R N T L$ gene, rs2278749 } \\
\hline & \multicolumn{2}{|c|}{$\mathbf{T} / \mathbf{T}$} & \multicolumn{2}{|c|}{$\mathrm{C} / \mathrm{T}$} & \multicolumn{2}{|c|}{$\mathrm{C} / \mathrm{C}$} & \multicolumn{2}{|c|}{ Total } \\
\hline & $\mathbf{N}$ & $\%$ & $\mathbf{N}$ & $\%$ & $\mathbf{N}$ & $\%$ & $\mathbf{N}$ & $\%$ \\
\hline Yes & 0 & 0 & 23 & 57.5 & 33 & 24.6 & 56 & 31.3 \\
\hline No & 5 & 100 & 16 & 40 & 87 & 64.9 & 108 & 60.3 \\
\hline I do not know & 0 & 0 & 1 & 2.5 & 14 & 10.4 & 15 & 8.4 \\
\hline Total & 5 & 100 & 40 & 100 & 134 & 100 & 179 & 100 \\
\hline \multicolumn{9}{|l|}{$\chi^{2}=19.52 \mathrm{df}=4 \mathrm{p}=0.001$} \\
\hline \multirow[t]{3}{*}{ The level of Vital Exhaustion } & \multicolumn{8}{|c|}{ Type of $A R N T L$ gene, rs2278749 } \\
\hline & \multicolumn{2}{|c|}{$\mathbf{T} / \mathbf{T}$} & \multicolumn{2}{|c|}{$\mathrm{C} / \mathrm{T}$} & \multicolumn{2}{|c|}{$\mathrm{C} / \mathrm{C}$} & \multicolumn{2}{|c|}{ Total } \\
\hline & $\mathbf{N}$ & $\%$ & $\mathbf{N}$ & $\%$ & $\mathbf{N}$ & $\%$ & $\mathbf{N}$ & $\%$ \\
\hline High & 0 & 0 & 5 & 12.5 & 4 & 3 & 9 & 5 \\
\hline Moderate & 0 & 0 & 15 & 37.5 & 43 & 32.1 & 58 & 32.4 \\
\hline Low & 5 & 100 & 20 & 50 & 87 & 64.9 & 112 & 62.6 \\
\hline Total & 5 & 100 & 40 & 100 & 134 & 100 & 179 & 100 \\
\hline$\chi^{2}=10.0 \mathrm{df}=4 \mathrm{p}<0.05$ & & & & & & & & \\
\hline
\end{tabular}

Table 2c 


\begin{tabular}{|c|c|c|c|c|c|c|c|c|}
\hline \multirow{3}{*}{$\begin{array}{l}\text { Jenkins test } \\
\text { If you have agreed with your spouse (or other) to } \\
\text { meet at a specific time, how often do you be late? }\end{array}$} & \multicolumn{8}{|c|}{ Type of $A R N T L$ gene, rs2278749 } \\
\hline & \multicolumn{2}{|c|}{$\mathbf{T} / \mathbf{T}$} & \multicolumn{2}{|c|}{$\mathrm{C} / \mathrm{T}$} & \multicolumn{2}{|c|}{$\mathrm{C} / \mathrm{C}$} & \multicolumn{2}{|c|}{ Total } \\
\hline & $\mathbf{N}$ & $\%$ & $\mathbf{N}$ & $\%$ & $\mathbf{N}$ & $\%$ & $\mathbf{N}$ & $\%$ \\
\hline Occasionally & 0 & 0 & 15 & 37.5 & 16 & 11.9 & 31 & 17.3 \\
\hline Rarely & 3 & 60 & 13 & 32.5 & 75 & 56 & 91 & 50.8 \\
\hline I'm never late & 2 & 40 & 12 & 30.0 & 43 & 32 & 57 & 31.8 \\
\hline Total & 5 & 100 & 40 & 100 & 134 & 100 & 179 & 100 \\
\hline$\chi^{2}=16.08 \mathrm{df}=6 \mathrm{p}=0.01$ & & & & & & & & \\
\hline
\end{tabular}

Table 2d

\begin{tabular}{|l|c|c|c|c|c|c|c|c|}
\hline Anxiety scale & \multicolumn{8}{|c|}{ Type of ARNTL gene, rs2278749 } \\
\hline & \multicolumn{2}{|c|}{ T/T } & \multicolumn{2}{c|}{ C/T } & \multicolumn{2}{c|}{ C/C } & \multicolumn{2}{c|}{ Total } \\
\hline I'm quickly upset & $\mathbf{N}$ & $\mathbf{\%}$ & $\mathbf{N}$ & $\mathbf{\%}$ & $\mathbf{N}$ & $\mathbf{\%}$ & $\mathbf{N}$ & $\mathbf{\%}$ \\
\hline Agree & 0 & 0 & 19 & 47.5 & 29 & 22.1 & 48 & 27.3 \\
\hline Disagree & 5 & 100 & 21 & 52.5 & 102 & 77.9 & 128 & 72.7 \\
\hline Total & 5 & 100 & 40 & 100 & 131 & 100 & 176 & 100 \\
\hline$\chi^{2}=13.06 \mathrm{df}=2 \mathrm{p}=0.01$ & 0.00 \\
\hline
\end{tabular}

Table 2e

\begin{tabular}{|c|c|c|c|c|c|c|c|c|}
\hline \multirow{3}{*}{$\begin{array}{l}\text { Hostility scale } \\
\text { It's safer not to trust anyone }\end{array}$} & \multicolumn{8}{|c|}{ Type of $A R N T L$ gene, rs2278749 } \\
\hline & \multicolumn{2}{|c|}{$\mathbf{T} / \mathbf{T}$} & \multicolumn{2}{|c|}{$\mathrm{C} / \mathrm{T}$} & \multicolumn{2}{|c|}{$\mathrm{C} / \mathrm{C}$} & \multicolumn{2}{|c|}{ Total } \\
\hline & $\mathbf{N}$ & $\%$ & $\mathbf{N}$ & $\%$ & $\mathbf{N}$ & $\%$ & $\mathbf{N}$ & $\%$ \\
\hline Agree & 0 & 0 & 14 & 35 & 68 & 50.7 & 82 & 45.8 \\
\hline Disagree & 5 & 100 & 26 & 65 & 66 & 49.3 & 97 & 54.2 \\
\hline Total & 5 & 100 & 40 & 100 & 134 & 100 & 179 & 100 \\
\hline$\chi^{2}=7.43 \mathrm{df}=2 \mathrm{p}<0.05$ & & & & & & & & \\
\hline
\end{tabular}

Table 2f

Table 2: Frequency distribution of rs2278749 genotypes of the ARNTL gene in males 25-44 years in Novosibirsk depending on psychological characteristics.

There was no association of rs2278749 genotypes of the ARNTL gene and sleep disorders on the questionnaire "4-item Jenkins Sleep Questionnaire" (JSQ) depending on both in terms of sleep quality and duration of sleep ( $\mathbf{P}=0.26$ and $\mathbf{P}=0.30)$

The question was asked: "How often, during the last month, do you have disturbing visions during sleep?". Only 7.5\% persons with $\mathrm{C} / \mathrm{T}$ genotype experienced similar difficulties for 22 days or more. C/T - 7,5\%; 27,5\% persons with C/T and 20\% with T/T genotype experienced disturbing visions for 4 - 7 days per month while persons with $\mathrm{C} / \mathrm{C}$ more often answered that they did not have disturbing visions $-42,5 \%\left(\chi^{2}=16.35 \mathrm{df}=8 \mathrm{p}<0.05\right)$.
Question: "How frequent during the last month did you wake up tired and exhausted after a normal sleep?" showed that $40 \%$ of persons with $\mathrm{T} / \mathrm{T}$ genotype have similar problems one to three times a month and persons with the $\mathrm{C} / \mathrm{T}$ genotype $(7.5 \%)$ more often experienced this problem - from fifteen days to three weeks $\left(\chi^{2}=18.71 \mathrm{df}=8 \mathrm{p}<0.01\right)$. Males with the $\mathrm{C} / \mathrm{T}$ heterozygous genotype $(57.3 \%)$ woke up more often with a feeling of exhaustion and fatigue $\left(\chi^{2}=19.52 \mathrm{df}=4 \mathrm{p}=0.001\right)$. 
Also, people with the $\mathrm{C} / \mathrm{T}$ genotype were more likely to experience a high level of vital exhaustion $-12.5 \%$ and moderate level of vital exhaustion $-37.5 \%\left(\chi^{2}=10.0 \mathrm{df}=4 \mathrm{p}<0.05\right)$.

Persons with $\mathrm{T} / \mathrm{T}$ genotype turned out to be more punctual and more often answered that they "do not late" (40\%) $\left(\chi^{2}=16.08 \mathrm{df}\right.$ $=6 \mathrm{p}=0.01$ ).

Persons with $\mathrm{C} / \mathrm{T}$ genotype agreed with the statement that they are "quickly upset" (47.5\%) compared to those with $\mathrm{C} / \mathrm{C}$ genotype (22.1\%) $\left(\chi^{2}=13.06 \mathrm{df}=2 \mathrm{p}=0.01\right)$.

$50.7 \%$ of men with the $\mathrm{C} / \mathrm{C}$ genotype believed it was safer not to trust anyone, while $65 \%$ of men with the heterozygous $\mathrm{C} / \mathrm{T}$ genotype did not agree with this statement $\left(\chi^{2}=7.43 \mathrm{df}=2 \mathrm{p}<0.05\right)$.

\section{Discussion}

In the studied population of men aged $25-44$ years it was found that the most common rs2278749 genotype of the ARNTL gene was the $\mathrm{C} / \mathrm{C}$ homozygous genotype $-74.9 \%$, the second most prevalent heterozygous C/T genotype was $22.3 \%$ and only $2.8 \%$ of individuals in the population had the T/T homozygous genotype, which is consistent with the results obtained for other European populations [15]. Considering the association of the rs2278749 genotypes of the ARNTL gene with affective disorders we identified several components that showed the strongest associations with the polymorphic variants of the studied gene. One of the most severe stressful situations is a serious conflict in the family. In our population persons with the $\mathrm{C} / \mathrm{T}$ heterozygous genotype more often than others noted that they experienced similar situations during the year, although they did not take them "to heart". On the contrary, men who had two $\mathrm{T}$ alleles in their genotype were less stress resistant. Nevertheless, persons with the $\mathrm{C} / \mathrm{T}$ genotype were more likely to experience their frustrations and had trouble sleeping especially since they had much more anxious dreams during the month. Men who carry the $\mathrm{T}$ allele, both homozygotes (T/T genotype) and heterozygotes (C/T genotype), woke up more often, tired and exhausted. In addition, persons with the $\mathrm{C} / \mathrm{T}$ genotype more often than others experienced a high level of vital depletion and were more upset because of any unpleasant situations in life. On the contrary men carrying the genotype were more hostile and thought it was safer not to trust anyone.

To summarize the above we can note that males with the $\mathrm{T}$ allele in the rs2278749 genotype of the ARNTL gene were more prone to anxiety, more often experienced life exhaustion, more painfully endured stressful situations in the family, more often had sleep problems. Our results confirm the findings of other researchers concerning the identification of individual polymorphic variants of the ARNTL gene which lead to possible desynchronization and disturbance of the circadian rhythm and accordingly to affective disorders [10].

\section{Conclusion}

- The most common genotype rs2278749 of the $A R N T L$ gene in the open population of men 25-44 years was the homozygous $\mathrm{C} / \mathrm{C}$ genotype $-74.9 \%$. The $\mathrm{C} / \mathrm{T}$ genotype was in $22.3 \%$ and $\mathrm{T} / \mathrm{T}$ genotype in $2.8 \%$ of males.

- $\quad$ Persons with the $\mathrm{C} / \mathrm{T}$ genotype more often experienced serious conflicts in the family, experienced their frustrations more, they often had disturbing dreams, and they woke up tired and exhausted; in addition, they were more likely to experience high levels of vital exhaustion and they were more upset.

- $\quad$ Persons with the T/T genotype were more likely to take "close to heart" troubles and were more punctual.

- Persons with the $\mathrm{C} / \mathrm{C}$ genotype were more hostile, inclined to trust no one, practically "never" took negative situations "close to heart" and less often had disturbing dreams.

\section{Support}

- This study partially supported by a grant.

- $\quad$ Found Welcome Trust (064947/Z/01/Z and WT081081AIA).

- $\quad$ This study partially supported by a grant.

- Russian Humanitarian Science Foundation \# 14-06-00227.

- The research was carried out under the state assignment within the framework of budget theme No. AAAA-A17-117112850280-2.

\section{Conflict of Interest}

None declared.

\section{Bibliography}

1. Murray C and Lopez A. "The Global Burden of Disease". Harvard University Press; Cambridge (1996).

2. Partonen T and Magnusson A. "Seasonal Affective Disorder". Oxford University Press; Oxford (2001).

3. Benca RM., et al. "Sleep and psychiatric disorders. A metaanalysis". Archives of General Psychiatry 49 (1992): 651-668. 
4. Gjessing R. "Contribution to the Somatology of Periodic Catatonia”. Pergamon; Oxford (1976).

5. Dunlap JC. "Molecular bases for circadian clocks". Cell 96 (1999): 271-290.

6. Albrecht U and Eichele G. "The mammalian circadian clock". Current Opinion in Genetics and Development 13 (2003): 271277.

7. Hirota T and Fukada Y. "Resetting mechanism of central and peripheral circadian clocks in mammals". Zoology Science 21 (2004): 359-368.

8. Hosoda H., et al. "A BMAL1 mutant with arginine 91 substituted with alanine acts as a dominant negative inhibitor". Gene 338 (2004): 235-241.

9. Li JZ., et al. "Circadian patterns of gene expression in the human brain and disruption in major depressive disorder". Neuroscience PNAS 110.24 (2013): 9950-9955.

10. Jenkins CD., et al. "A scale for the estimation of sleep problems in clinical research". Journal of Clinical Epidemiology 41 (1988): 313-321.

11. WHO MONICA psychosocial optional study. Suggested measurement instruments. Copenhagen: World Health Organization (1988).

12. WHO MONICA Project prepared by Kuulasmaa K. et al. Baseline population survey data book. MONICA Memo 178 A: Helsinki (1990).

13. Bühl A., et al. "Einführung in die moderne Datenanalyse unter Windows" (2005).

14. Epi Info 7 is public domain statistical software for epidemiology developed by Centers for Disease Control and Prevention (CDC) in Atlanta, Georgia (USA).

15. Wellcome Trust Case Control Consortium. "Genome-wide association study of 14,000 cases of seven common diseases and 3,000 shared controls". Nature 447.7145 (2007): 661-678.

\section{Assets from publication with us}

- Prompt Acknowledgement after receiving the article

- Thorough Double blinded peer review

- Rapid Publication

- Issue of Publication Certificate

- High visibility of your Published work

Website: www.actascientific.com/

Submit Article: www.actascientific.com/submission.php

Email us: editor@actascientific.com

Contact us: +919182824667 